\title{
ANTIBACTERIAL ACTIVITY OF DL 473, A NEW SEMISYNTHETIC RIFAMYCIN DERIVATIVE
}

\author{
Vittorio Arioli, Marisa Berti, Giuliana Carniti, \\ Eleonora Randisi, Elsa Rossi and Roberto Scotti \\ Research Laboratories, Gruppo Lepetit S.p.A., Via Durando, 38, Milan, Italy \\ (Received for publication April 23, 1981)
}

\begin{abstract}
DL 473, a new semisynthetic rifamycin, was $2 \sim 10$ times more active in vitro than rifampicin (RAMP) against several clinical isolates of Mycobacterium tuberculosis and only slightly less active than RAMP against Gram-positive and Gram-negative bacteria. It showed excellent therapeutic activity in mice in experimental infections caused by Staphylococcus aureus, Streptococcus pyogenes group A, Streptococcus pneumoniae and Klebsiella pneumoniae. In the experimental TB infection in the mouse DL 473 was clearly more active than isoniazide and RAMP, two of the most effective antitubercular drugs in current use. The $\mathrm{LD}_{50}$ in the mouse was significantly higher than that of RAMP and the half-life was about 5 times longer than that of RAMP.
\end{abstract}

In 1975 we reported the antibacterial activities of a series of piperazinyl hydrazones of 3-formyl rifamycin $\mathrm{SV}^{11}$.

The unusually large half-life value in animals characteristic of some of these derivatives prompted us to synthesize some other related compounds; of these the 3-[(4-cyclopentyl-1-piperazinyl)iminomethyl]rifamycin SV derivative (DL 473) was selected for deeper evaluation.

The activity of DL 473 on Chlamydia trachomatis ${ }^{2,3)}$ and Mycobacterium leprae ${ }^{4)}$ has already been reported. We report here on the antibacterial activity of DL 473 on a number of Gram-positive and Gram-negative bacteria and on Mycobacterium tuberculosis. The synthesis and physicochemical characteristics of DL 473 will be reported elsewhere.

\section{Materials and Methods}

Bacterial Strains

The organisms used in this study included both laboratory strains and clinical isolates of Grampositive and Gram-negative bacteria, one laboratory strain (H37Rv ATCC 9360) and 23 clinical isolates of Mycobacterium tuberculosis.

Minimal Inhibitory Concentrations (MIC)

The MIC were determined by the broth-dilution technique as described by ARIOLI et al..$^{5}$.

Bactericidal Activity on M. tuberculosis

A 7-day old culture of M. tuberculosis H37Rv ATCC 9360 was diluted in TBG medium (Difco-TB broth $+10 \%$ Difco-albumin and $10 \%$ glycerol) in order to obtain a cell concentration of $10^{6}$ bacteria $/ \mathrm{ml}$. The culture was divided into five parts which were treated with 10 or 100 times the MIC (determined in the same medium) of DL 473 or RAMP; the 5th culture served as control. Incubation at $37^{\circ} \mathrm{C}$ was for 8 days with aliquots withdrawn at intervals and plated on Difco-Dubos agar supplemented with $1 \%$ activated charcoal (Merck) and $10 \%$ albumin to determine the number of colony forming units (CFU). The plates were read after 4 weeks of incubation at $37^{\circ} \mathrm{C}$.

Mutation Rate

Staphylococcus alureus ATCC 6538 was used as the test strain. Twenty ml of Oxido No. 2 nutrient 
broth were inoculated with $10^{2}$ bacteria/ml and then distributed in 20 tubes. After overnight incubation at $37^{\circ} \mathrm{C}$ each sample was plated on nutrient agar $+0.5 \mu \mathrm{g} / \mathrm{ml}$ of DL 473 . Another culture grown in the same conditions served to determine the number of total $\mathrm{CFU} / \mathrm{ml}$. The mutation rate per cell per generation was determined by the method of ClOwES and HAYES ${ }^{()}$.

Experimental Infections

$\mathrm{CF}_{1}$ albino mice weighing $18 \sim 22 \mathrm{~g}$ were used for all the experimental infections. The therapeutic effect of DL 473 in experimental infections with Gram-positive and Gram-negative bacteria was evaluated as described by ARIOLI et al. ${ }^{\text {) }}$.

For the tubercular infection, mice were inoculated intravenously with $0.5 \mathrm{ml}$ of a suspension of M. tuberculosis H37Rv ATCC 9360 prepared by centrifuging a 10-day old culture in TBG and resuspending the cells in sterile saline to a concentration of about $2 \times 10^{7} / \mathrm{ml}$. At the 10th day after the infection the bacterial lung load, determined by the method of KRADOLFER et al. ${ }^{7)}$, ranged from $2 \times 10^{8}$ to $8 \times 10^{6}$ in various experiments. Oral treatment was started $7 \sim 11$ days after infection; the schedules are indicated in the tables. DL 473 and RAMP were given in solution in $0.067 \mathrm{M}$ phosphate buffer $(\mathrm{pH} 7.38)+10 \%$ dimethylformamide; isoniazid $(\mathrm{INH})$ was administered in aqueous solution. The $50 \%$ survival time $\left(\mathrm{ST}_{50}\right)$ was calculated by the method of LITCHFIELD ${ }^{8)}$ and the $50 \%$ effective dose $\left(\mathrm{ED}_{50}\right)$ by the method of LITCHFIELD and WILCOXON ${ }^{9)}$.

\section{Results}

\section{In Vitro Studies}

DL 473 showed a greater in vitro activity than RAMP on M. tuberculosis (Table 1); the various strains were 2- 10-fold more susceptible to DL 473. On the contrary the MIC of DL 473 on Grampositive and Gram-negative strains were slightly higher than those of RAMP, both for laboratory strains (Table 2), and for clinical isolates (Table 3).

The MIC of DL 473 was somewhat influenced by serum; an increase of 2- 8-fold in MIC was observed when the concentration of bovine serum in the culture medium was increased from $10 \%$ to $70 \%$. Under the same conditions, the MIC of RAMP increased by no more than two-fold.

The bactericidal activity of DL 473 on M. tuberculosis H37Rv was at least as good as that of RAMP. After 7 days of incubation with $3 \mu \mathrm{g} / \mathrm{ml}$ of RAMP the initial inoculum $\left(\sim 10^{8}\right.$ cell $\left./ \mathrm{ml}\right)$ was reduced by $99.9 \%$.

The mutation rate toward resistance to DL 473 in $S$. aureus was $2.0 \times 10^{-8} /$ cell/generation. The value for RAMP was $2.6 \times 10^{-8} /$ cell/generation. DL 473 showed cross-resistance with RAMP as demonstrated by absence of activity against a RAMP-resistant mutant of S. aureus strain Tour (Table 2).

\section{Experimental Infections}

DL 473 was very effective in curing infections due to Gram-positive bacteria, but it did not possess significant activity in infections due to Gram-negative organisms, with the exception of $K$. pneumoniae (Table 4).

In contrast, in the experimental TB infection in mice DL 473 demonstrated clearly higher activity than RAMP. In Table 5, we report the $\mathrm{ST}_{50}$ 's obtained with different doses of DL 473 and RAMP and treatment periods ranging from 2 to 15 days. With the same treatment schedules, DL 473 gave $\mathrm{ST}_{50}$ values about 3 times higher than those of RAMP. Even with higher total doses of RAMP (4 5 times that of DL 473) RAMP was still less effective than DL 473. In another experiment, mice were treated for 3 months with various doses of the two compounds. At the dose of $20 \mathrm{mg} / \mathrm{kg}$ once weekly, DL 473 gave an ST 50 value 2.5 times that of RAMP (Table 6). DL 473 at $10 \mathrm{mg} / \mathrm{kg}$ once weekly 
Table 1. In vitro activity of DL 473 and RAMP on Mycobacterium tuberculosis.

\begin{tabular}{|c|c|c|c|}
\hline & \multirow{2}{*}{ Strains } & \multicolumn{2}{|c|}{$\mathrm{MIC}(\mu \mathrm{g} / \mathrm{ml})$} \\
\hline & & DL 473 & RAMP \\
\hline \multicolumn{2}{|c|}{ M.tuberculosis H37Rv ATCC 9360} & 0.05 & 0.5 \\
\hline$"$ & L 188 & 0.2 & 1 \\
\hline$"$ & L 189 & 0.1 & 0.5 \\
\hline$" \prime$ & L 191 & 0.1 & 0.2 \\
\hline$"$ & L 192 & 0.1 & 0.5 \\
\hline$"$ & L 212 & 0.1 & 0.5 \\
\hline$"$ & L 213 & 0.2 & 0.5 \\
\hline$"$ & L 215 & 0.05 & 0.5 \\
\hline$"$ & L 400 & 0.1 & 0.2 \\
\hline$"$ & L 402 & 0.05 & 0.5 \\
\hline$"$ & L 404 & 0.05 & 0.2 \\
\hline$"$ & L 405 & 0.1 & 0.5 \\
\hline$n$ & L 407 & 0.1 & 0.5 \\
\hline$"$ & L 1022 & 0.08 & 0.31 \\
\hline$"$ & L 1023 & 0.04 & 0.16 \\
\hline$n$ & L 1024 & 0.16 & 0.31 \\
\hline " & L 1025 & 0.08 & 0.31 \\
\hline$"$ & L 1027 & 0.04 & 0.16 \\
\hline$"$ & L 1028 & 0.08 & 0.31 \\
\hline$n$ & L 1029 & 0.16 & 0.31 \\
\hline$"$ & L 1030 & 0.02 & 0.04 \\
\hline$"$ & L 1032 & 0.08 & 0.31 \\
\hline$"$ & L 1033 & 0.16 & 0.62 \\
\hline$"$ & L 1034 & 0.16 & 0.31 \\
\hline
\end{tabular}

The $\mathrm{L}$ strains are clinical isolates.

was at least as effective as $60 \mathrm{mg} / \mathrm{kg}$ of RAMP per week (given as $10 \mathrm{mg} / \mathrm{kg} 6$ days of the week). These experiments indicated that both for brief (7 days) and long (3 months) treatment schedules $5 \sim 6$ times as much RAMP as DL 473 is needed to get the same $\mathrm{ST}_{50}$ value. We also compared the therapeutic activity of single administrations
Table 2. In vitro activity of DL-473 and RAMP on Gram-positive and Gram-negative bacteria.

\begin{tabular}{l|lc}
\hline \multirow{2}{*}{ Strains } & \multicolumn{2}{|c}{ MIC $(\mu \mathrm{g} / \mathrm{ml})$} \\
\cline { 2 - 3 } & DL 473 & RAMP \\
\hline Staphylococcus aureus ATCC 6538 & 0.005 & 0.002 \\
Staphylococcus aureus Tour & 0.005 & 0.005 \\
Staphylococcus aureus Tour & $>100$ & $>100$ \\
RAMP-r & 0.05 & 0.02 \\
Streptococcus pyogenes C 203 ISM & 0.05 & 0.01 \\
Streptococcus faecalis ATCC10541 & 0.05 & 0.01 \\
Streptococcus pneumoniae UC 41 & 0.05 & 5 \\
Proteus vulgaris X 19H ATCC 881 & 5 & 1 \\
Escherichia coli ATCC 10536 & 2 & 5 \\
Klebsiella pneumoniae ATCC10031 & 10 & 10 \\
Pseudomonas aeruginosa ATCC & 10 & \\
10145 & & \\
\hline
\end{tabular}

Table 3. In vitro activity of DL 473 and of RAMP on Gram-positive and Gram-negative clinical isolates.

\begin{tabular}{|c|c|c|c|}
\hline \multirow[t]{2}{*}{ Organism } & \multirow{2}{*}{$\begin{array}{l}\text { No. of } \\
\text { tested } \\
\text { strain }\end{array}$} & $\begin{array}{c}\text { Geometric } \\
\text { mean }\end{array}$ & $\begin{array}{c}\text { MIC } \\
(\mu \mathrm{g} / \mathrm{ml})\end{array}$ \\
\hline & & DL 473 & RAMP \\
\hline Staphylococcus sp. & 9 & 0.021 & 0.0089 \\
\hline $\begin{array}{l}\text { Streptococcus } \mathrm{sp} . \\
\text { (except D streptococci) }\end{array}$ & 8 & 0.13 & 0.05 \\
\hline S. pneumoniae & 5 & 2.7 & 1.4 \\
\hline D streptococci & 6 & 2.2 & 0.9 \\
\hline Haemophilus sp. & 9 & 1.6 & 0.46 \\
\hline Neisseria sp. & 7 & 0.85 & 0.16 \\
\hline E. coli & 6 & 7.0 & 3.5 \\
\hline Enterobacter sp. & 9 & 40 & 18 \\
\hline Klebsiella sp. & 5 & 44 & 19 \\
\hline P. mirabilis & 6 & 40 & 18 \\
\hline Proteus (indol positive) & 8 & 6.8 & 4.8 \\
\hline S. marcescens & 5 & 11 & 3.1 \\
\hline P. aeruginosa & 4 & 12 & 4.4 \\
\hline
\end{tabular}

(7 days after the infection) of DL 473, RAMP or INH. The $\mathrm{ST}_{50}$ values corresponding to the various doses of the drugs are in Fig. 1 a; the dose-effect curves constructed for each compound and the calculated $\mathrm{ED}_{50}$ values are in Fig. $1 \mathrm{~b}$. The $\mathrm{ST}_{50}$ values obtained with doses of DL 473 between 5 and $40 \mathrm{mg} / \mathrm{kg}$ were consistently significantly higher $(\mathrm{p}<0.05)$ than those obtained with equal doses of RAMP. The values at 10,20 and $40 \mathrm{mg} / \mathrm{kg}$ of DL 473 were also greater than those obtained at the same doses of INH, but here the differences were statistically significant only at $20 \mathrm{mg} / \mathrm{kg}$. The $\mathrm{ST}_{50}$ values at 20,10 and $5 \mathrm{mg} / \mathrm{kg}$ of RAMP were not significantly higher than that of the infected controls $\left(\mathrm{ST}_{50}=18.2\right.$ days). The $\mathrm{ED}_{50}$ value for $\mathrm{DL} 473$ was significantly lower than those of RAMP and of INH. 
Table 4. Activity of DL 473 and RAMP in experimental infections of mice with Gram-positive and Gram-negative bacteria.

\begin{tabular}{|c|c|c|c|c|}
\hline \multirow{3}{*}{ Organism } & \multicolumn{4}{|c|}{$\mathrm{ED}_{50}(\mathrm{mg} / \mathrm{kg})$} \\
\hline & \multicolumn{2}{|c|}{ DL 473} & \multicolumn{2}{|c|}{ RAMP } \\
\hline & per os & s.c. & per os & s.c. \\
\hline Staphylococcus aureus Tour & 0.22 & 0.18 & 0.12 & 0.11 \\
\hline Streptococcus pyogenes C 203 ISM & 2.64 & 1.74 & 0.93 & 0.76 \\
\hline Streptococcus pneumoniae Felton UC 41 & 3.55 & 2.87 & 1.87 & 1.77 \\
\hline Escherichia coli SKF 12140 & $>200$ & $>200$ & 65.3 & 37.5 \\
\hline Salmonella typhimurium $\mathrm{Kh}$ & $>200$ & $>200$ & 81.2 & 75.8 \\
\hline Klesbiella pneumoniae ISM & 64.3 & 68.9 & 16.2 & 23 \\
\hline Proteus vulgaris X 19 H ATCC 881 & $>120$ & $>120$ & 53.6 & 21.8 \\
\hline Pseudomonas aeruginosa ATCC 10145 & $>100$ & $>100$ & 61.6 & 37.9 \\
\hline
\end{tabular}

Table 5. Experimental TB (H37Rv) infection in mice (treatment started 10 days after infection).

\begin{tabular}{|c|c|c|c|c|}
\hline \multicolumn{2}{|c|}{ Treatment } & \multirow{2}{*}{$\begin{array}{c}\text { Single dose } \\
(\mathrm{mg} / \mathrm{kg}) \times \text { No. of } \\
\text { administrations }= \\
=\text { total dose }\end{array}$} & \multirow{2}{*}{$\begin{array}{l}\text { Days of } \\
\text { administration }\end{array}$} & \multirow{2}{*}{$\begin{array}{c}\mathrm{ST}_{50} \text { (days) } \\
(95 \% \text { confidence limits })\end{array}$} \\
\hline No. & Drug & & & \\
\hline & Controls & - & - & $21(25 \sim 17)$ \\
\hline 1 & DL 473 & $10 \times 3=30$ & $10,17,24$ & $110(122 \sim 99)$ \\
\hline 2 & RAMP & $10 \times 3=30$ & $10,17,24$ & $36(45 \sim 29)$ \\
\hline 3 & DL 473 & $20 \times 2=40$ & 10,17 & $105(125 \sim 88)$ \\
\hline 4 & RAMP & $20 \times 2=40$ & 10,17 & $42.5(55 \sim 33)$ \\
\hline 5 & RAMP & $20 \times 8=160$ & $10,11,12,13,14,15,16,17$ & $87(105 \sim 72)$ \\
\hline 6 & RAMP & $10 \times 15=150$ & $10 \stackrel{\text { daily }}{\longrightarrow} 24$ & $76(101 \sim 57)$ \\
\hline
\end{tabular}

Differences were statistically significant $(p<0.05)$ between treatment No. 1 and treatments No. 2,5 and 6 and between treatments No. 3 and No. 4 .

Fig. 1. Activity of DL 473, INH, and RAMP in experimental TB (H37Rv) infection in mice (groups of 10 mice each).

a) $\mathrm{ST}_{50}$ at the various doses. b) Dose-effect curves at 27 days post infection.

The numbers on the lines refer to the $\mathrm{ED}_{50}$ values with $95 \%$ confidence limits in parenthesis. All infected controls died by day 22 .
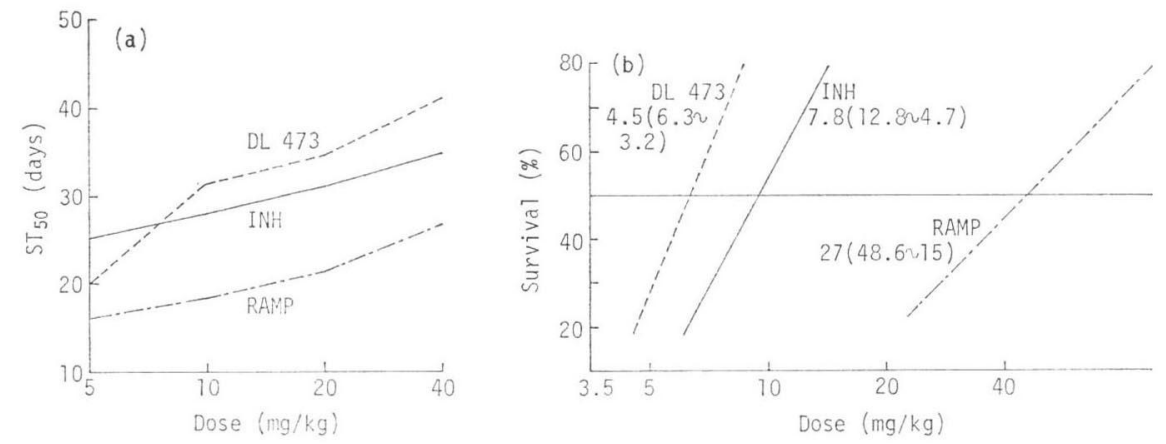

The next experiment was aimed at determining the comparative bactericidal effects of RAMP and DL 473, each in combination with INH in the mouse. Table 7 shows the results for individual mice in the various groups. The reduction of the bacterial lung load obtained upon treatment with $10 \mathrm{mg} / \mathrm{kg}$ 
Table 6. Experimental TB ( $\mathrm{H} 37 \mathrm{Rv})$ infection in mice (treatment started 10 days after infection: 3 months treatment).

\begin{tabular}{lc|c|c}
\hline Treatment & $\begin{array}{c}\text { Single dose } \\
(\mathrm{mg} / \mathrm{kg}) \times \text { weekly } \\
\text { No. of } \\
\text { administra- } \\
\text { tions=weekly } \\
\text { total dose }\end{array}$ & $\begin{array}{c}\mathrm{ST}_{50} \text { (days) } \\
\text { (95\% con- } \\
\text { fidence limits) }\end{array}$ \\
\hline & Controls & - & $28(38.9 \sim 20.1)$ \\
1 & DL 473 & $10 \times 1=10$ & $350(409 \sim 299)$ \\
2 & DL 473 & $20 \times 1=20$ & $415(473 \sim 364)$ \\
3 & RAMP & $20 \times 1=20$ & $170(195 \sim 147)$ \\
4 & RAMP & $10 \times 6=60$ & $327(382 \sim 279)$ \\
\hline
\end{tabular}

Differences were statistically significant $(p<0.05)$ between treatments No. 1 and No. 3 and between treatment No. 2 and treatments No. 3 and No. 4. of DL $473+40 \mathrm{mg} / \mathrm{kg}$ of INH was significantly greater than that obtained with $10 \mathrm{mg} / \mathrm{kg}$ of $\mathrm{RAMP}+40 \mathrm{mg} / \mathrm{kg}$ of $\mathrm{INH}$ at all times sampled except at 130 days of treatment. Here the absence of significance is probably due to relatively low number of observations. When $20 \mathrm{mg} / \mathrm{kg}$ of DL $473+40 \mathrm{mg} / \mathrm{kg}$ of INH was compared with $20 \mathrm{mg} / \mathrm{kg}$ of RAMP $+40 \mathrm{mg} / \mathrm{kg}$ of INH the differences were again statistically significant at all times except after 170 days of treatment. Only in the case of combined treatment with DL $473+$ INH were some of the lungs completely sterilized. INH at $40 \mathrm{mg} / \mathrm{kg}$ was significantly less effective in reducing the pulmonary load than were most of the other treatments; the exceptions were RAMP $10 \mathrm{mg} / \mathrm{kg}+\mathrm{INH} 40 \mathrm{mg} / \mathrm{kg}$ at the 90 th day of treatment, and RAMP $20 \mathrm{mg} / \mathrm{kg}$ or DL $47310 \mathrm{mg} / \mathrm{kg}+\mathrm{INH} 40 \mathrm{mg} / \mathrm{kg}$ at 50 days after the end of treatment. In this last case it should be noted that, nevertheless, at the day of sacrifice only 3 out of 10 mice were alive in the INH group whereas in the other groups survival ranged from 70 to $100 \%$. No cells resistant either to RAMP or to DL 473 were found in any group at any of the sampling times.

Table 7. Bacterial lung load (No. cells/lung) of TB infected mice.

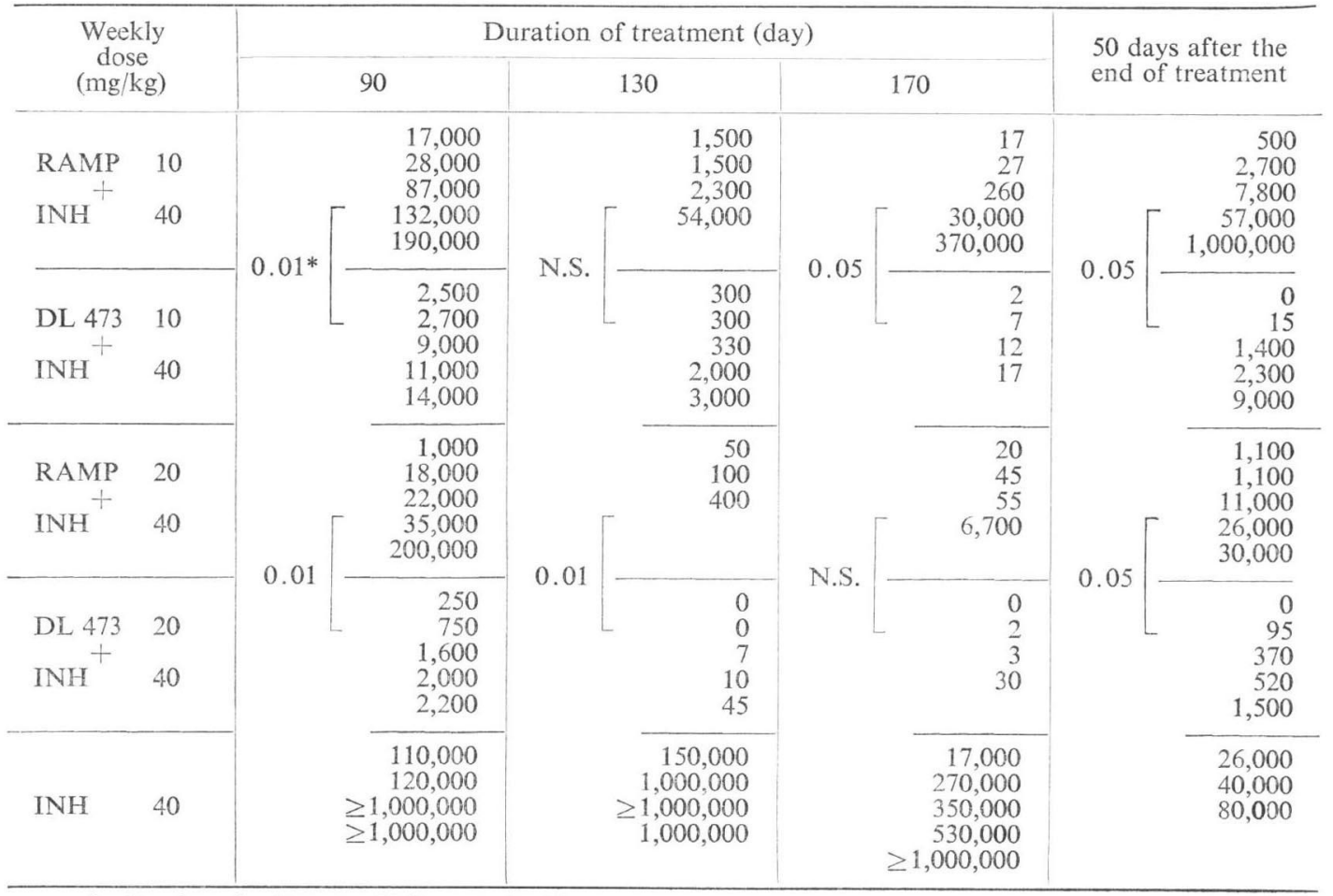

* P values for $\mathrm{F}$ test. N.S.: not significant 


\section{Discussion}

The results of these experiments underline some unique characteristics of DL 473 which suggest interesting prospects for the therapeutic use of this rifamycin derivative.

DL 473 had significant activity against Gram-positive bacteria both in vitro and in experimental septicemia; however its activity was generally slightly less than that of RAMP. Against Gram-negative bacteria, DL 473 was somewhat less active than RAMP in vitro and much less effective in experimental infections in the mouse.

DL 473 has a longer half-life in mice than RAMP ( 31 hours versus 6.5 hours); this is probably due to slower hepatic clearance and stronger binding to serum proteins by DL 473 than by RAMP ${ }^{10,11)}$. A longer half-life for DL 473 has also been demonstrated in $\operatorname{man}^{12)}$. This feature of DL 473 may limit its ability to cure very acute septicemic infections (in which death of the controls occurs within 48 hours) where attainment of high peak levels immediately after administration may be more important than prolonged blood levels. Therefore, it is not surprising that in such infections DL 473 showed $\mathrm{ED}_{50}$ values greater than those of RAMP, reflecting the activity ratio in vitro. However, it is not improbable that in slowly developing infections as clinical ones often are, the pharmacokinetics of DL 473 might be advantageous also in Gram-positive and Gram-negative bacterial infections.

For M. tuberculosis in vitro (both laboratory and clinical isolates) DL 473 was $2 \sim 10$ times as active as RAMP in terms of MIC and at least as good as RAMP in terms of bactericidal activity. This greater in vitro activity was confirmed by the therapeutic potency of DL 473 in the experimental tubercular infection of the mouse which was clearly greater than that of RAMP and (though the difference was smaller) of INH. This greater therapeutic effectiveness was measurable both in terms of prolonged survival times of treated animals as compared with controls, and in terms of rapidity and extent of the reduction of the pulmonary bacterial load (at least in combination with INH). It is very probable that this high effectiveness was due, at least in part, to the more prolonged blood levels.

On the basis of these results, one may reasonably expect to obtain equivalent therapeutic results by using doses of DL 473 significantly lower than those of RAMP or, alternatively, to obtain greater therapeutic effects with DL 473 by using doses equal to those of RAMP. Another feature of DL 473 is its lower acute toxicity $\left(\mathrm{LD}_{50}\right)$ in the mouse $(3300 \mathrm{mg} / \mathrm{kg}$ orally and $710 \mathrm{mg} / \mathrm{kg}$ intraperitoneally, as compared with 770 and $585 \mathrm{mg} / \mathrm{kg}$ for RAMP). Combined with its better antitubercular activity, this gives DL 473 a therapeutic index which is considerably higher than that of RAMP.

These various characteristics of DL 473 make it a new rifamycin with high therapeutic potential.

\section{References}

1) Cricchio, R.; V. Arioli \& G. C. LANCini: Hydrazones of 3-formylrifamycin SV. I. Hydrazones with $\mathrm{N}$-amino-N'-substituted piperazines: synthesis, antibacterial activity and other biological properties. Il Farmaco Ed. Scientifica 30: 605 619, 1975

2) Ridgway, G. L. \& I. D. OrIEL: Activity of antimicrobials against Chlamydia trachomatis in vitro. J. Antimicr. Chemoth. 5: 483 484, 1979

3) Ridgway, G. L.; S. Boulding \& V. HAM Po TANG: Activity of rifamycins against Chlamydia trachomatis in vitro. p. 1275. Current Chemotherapy and Infections Disease. Proceedings of the 11th Internatl. Congr. Chemoth. \& the 19th Intersci. Conf. Antimicr. Agents \& Chemoth., Boston, Mass., 1 5, October 1979. The American Society for Microbiology. Washington, DC. 1980

4) Pattyn, S. R. \& E. I. Saerens: Activity of three new rifamycin derivatives on the experimental infection by Mycobacterium leprae. Ann. Soc. Belge Med. Trop. 57: 169 173, 1977

5) Arioli, V.; R. Pallanza, S. Füresz \& G. Carniti: Rifampicin: a new rifamycin. I. Bacteriological studies. Arzneim.-Forsch. 17: 523 529, 1967

6) Clowes, R. C. \& W. Hayes: Experiments in microbial genetics. p. 22, John Wiley \& Sons Inc., NewYork, 1968

7) Kradolfer, F. \& R. Schnell: Curative effect of a course of monotherapy with rifampicin, isoniazid or streptomycin subsequent to combination treatment in murine tuberculosis. Arzneim.-Forsch. 23: $1462 \sim 1464,1973$

8) Litchild, J. T.: A method for rapid graphic solution of time-per cent effect curves. J. Pharmac. Exp. 
Ther. 97: 399 408, 1949

9) Litchfield, J. T., Jr. \& F. Wilcoxon: A simplified method of evaluating dose-effect experiments. J. Pharmac. Exp. Ther. 96: 99 113, 1949

10) Assandri, A.; T. Cristina \& L. Moro: Physiological disposition of a series of rifamycins in rat: a comparative study. J. Antibiotics 31: 894 901, 1978

11) Assandri, A.; A. Perazzi \& M. Berti: Studies of binding $\mathrm{C}_{3}$-substitute rifamycins to human and bovine serum albumin. J. Antibiotics 30: 409 415, 1977

12) Birmingham, A.T.; A.J. Coleman, M. L'E Orme, B.K. Park, N.J. Pearson, A.H. Short \& P.J. Southgate: Antibacterial activity in serum and urine following oral administration in man of DL 473 (a cyclopentyl derivative of rifampicin). Br. J. Clin. Pharmac. 6: 455 456 P, 1978 